\title{
Dental Granuloma
}

National Cancer Institute

\section{Source}

National Cancer Institute. Dental Granuloma. NCI Thesaurus. Code C4865.

A granuloma located at the root apex of a tooth. 